\title{
Interferon lambda induces antiviral response to herpes simplex virus 1 infection
}

\author{
K. LOPUŠNÁ² I. REŽUCHOVÁ ${ }^{1}$, P. KABÁT ${ }^{1,2^{*}}, \mathrm{M}$. KÚDELOVÁ ${ }^{*}$ \\ ${ }^{1}$ Institute of Virology, Slovak Academy of Sciences, Dúbravská cesta 9, 84505 Bratislava, Slovak Republic; ${ }^{2}$ Department \\ of Microbiology and Virology, Comenius University Bratislava, Slovak Republic
}

Received December 3, 2013; accepted November 10, 2014

\begin{abstract}
Summary. - Lambda interferons (IFN- $\lambda$ ) are known to induce potent antiviral response in a wide variety of target cells. They activate the same intracellular signalling pathways and have similar biological activities as IFN- $\alpha / \beta$, including antiviral activity, but signal via distinct receptor complex, which is expressed in a celland species-specific manner. IFN- $\lambda$ was reported to induce in vitro marked antiviral activity against various RNA viruses, but corresponding data on DNA viruses are sparse. Therefore we examined the IFN- $\lambda 1$ induced antiviral activity against two strains of herpes simplex virus 1, a highly pathogenic ANGpath and moderately pathogenic KOS. The antiviral response was determined in vitro in Vero cells, known as deficient in production of type I IFNs and in Vero E6 cells, responding to viral infection with abundant IFN- $\lambda$ production, although deficient in production of type I IFNs. The results showed that IFN- $\lambda 1$ induced in Vero cells higher antiviral activity against ANGpath strain than against KOS strain. In Vero E6 cells endogenous IFN- $\lambda$ induced higher antiviral activity against ANGpath strain than against KOS strain, but because of the virus induction of IFN- $\lambda$ expression the antiviral activity was detected later. The observed differences between the IFN- $\lambda 1$-induced antiviral activities against viral strains of various pathogenicity suggest that virus attributes may play role in the antiviral state of cells induced by IFN- $\lambda$.
\end{abstract}

Keywords: interferon lambda 1; herpes simplex virus 1; ANGpath strain; KOS strain; Vero cells; Vero E6 cells

\section{Introduction}

Interferons lambda (IFN- $\lambda$ ), discovered in early 2003 (Kotenko et al., 2003; Sheppard et al., 2003), belong to proteins of the IFN family, known by their ability to stimulate innate and adaptive immune mechanisms that contribute to the clearance of viral infections. IFN- $\lambda$ family members, produced in response to virus infections, participate in the establishment of an antiviral state. They share with type I IFNs not only functional similarity, including the ability

*Corresponding authors: E-mail: virupepo@savba.sk, virukude@ savba.sk; phone: +421-2-60296487, +421-2-59302434.

Abbreviations: IFN = interferon; IL = interleukin; HSV-1 = herpes simplex virus 1 ; HSV-2 = herpes simplex virus 2 ; MOI = multiplicity of infection; ISG = interferon-stimulated gene; $\mathrm{PFU}=$ plaque forming unit; p.i. $=$ post infection; TLR3 $=$ toll-like receptor 3 ; vhs $=$ virion host shutoff to induce an antiviral state in cells, but also expression patterns, trigger common signal transduction cascades and sets of stimulated genes (Onoguchi et al., 2007). The IFN- $\lambda$ subfamily (classified as type III IFN) contains four cytokines (IFN- $\lambda 1$, IFN- $\lambda 2$, and IFN- $\lambda 3$; first designed as interleukin29 (IL-29, IL-28A, and IL-28B) (reviewed by Lopušná et al., 2013). Recently, fourth family member, IFN- $\lambda 4$, was described. Its functional protein was identified only in primates and disrupted in individuals of a particular genotype (Prokurina-Olson et al., 2013).

IFN- $\lambda$ family members display potent antiviral activity in vivo and in vitro against a number of viruses in various cell types inhibiting their replication (Ank and Paludan, 2009). IFN- $\lambda 1$ exhibited antiviral effect in HT29, A549 and HaCaT cells infected with vesicular stomatitis virus, in HT29 and HepG2 cells infected with encephalomyocarditis virus, in human hepatoma cells infected with hepatitis $C$ virus, and in differentiated murine hepatocyte cells infected with hepa- 
titis B virus, just as well (Kotenko et al., 2003; Robek et al., 2005; Donnelly and Kotenko, 2010). IFN- $\lambda$ production was induced by Newcastle disease virus infection of mouse embryonic fibroblasts and by herpes simplex virus 2 (HSV-2), Sendai virus, and influenza A virus in different types of cells, including A549, Hela, Raji and U937 cells (Ank et al., 2006). The influenza A virus infection also induced IFN- $\lambda$ expression in monocyte-derived and plasmacytoid dendritic cells (Coccia et al., 2004). More recently, IFN- $\lambda 2$ and IFN$\lambda 3$ displayed an antiviral effect in A549 lung epithelial cell line infected with influenza A virus (Svetlikova et al., 2010). Despite intensive study, data on antiviral activity of IFN- $\lambda$ on cells infected with herpes simplex virus 1 (HSV-1) or HSV-2 are still missing. In vitro assays on the model of hepatocyte carcinoma HepG 2 cells revealed that IFN- $\lambda 1$ was capable to induce only limited activity against HSV-2 strains (MS and 333), whereas IFN- $\alpha$ potently restricted this virus. In further studies on cell types responsive to IFN- $\lambda$, epithelial cells in which HSV-2 is exclusively replicated during vaginal infection were tested using genital herpes model. The antiviral activity of IFN- $\lambda$ was induced after two days of epithelial cells infection with various doses of HSV-2 (Ank et al., 2008).

HSV-1 and HSV-2 are neurotropic viruses capable to infect epithelium cells of oral and genital mucosa and of the skin surface. Thereafter, the virus enters various mucosal or nerve endings from which it spreads to corresponding neurons. In target cells (neurons, microglia, and astrocytes), latent infection, the major obstacle in preventing eradication of the virus, is established (Guo et al., 2010). Depending on several factors, including the host immune status, the reactivation of HSV-1 or HSV-2 from latency may lead to a recurrent lytic infection in epidermal cells causing recurrent disease. HSV-1 latency within brain tissue appears to be related to spontaneous herpetic encephalitis and the most probably also to schizophrenia, polar psychotic disorders and Alzheimer's disease (Kúdelová and Rajčáni, 2013). In the studies on relation of toll-like receptor 3 (TLR3) immunity inborn errors to proclivity of children to HSV-1 encephalitis, neurons, oligodendrocytes and astrocytes were suggested to provide strong, intrinsic protective anti-HSV-1 immunity in the CNS (Lafaille et al., 2012; Li et al., 2012; Wang et al., 2012; Sorgeloos et al., 2013). Recent studies have shown that cells in the CNS possess intracellular innate immunity properties, having the ability to express IFNs including IFN- $\lambda$ (Li et al., 2011) and other antiviral factors which suppress and eliminate HSV-1 or HSV-2 in its target cells (Paul et al., 2007). However, the precise cellular and molecular mechanisms by which IFN- $\lambda$ is regulated upon viral and/or other cellular factors remain to be determined.

For studying the pathogenesis of HSV-1 and HSV-2, including mechanisms of virus host interactions, a number of clinical and laboratory-adapted strains of these viruses that differ in pathogenicity, virulence and/or cytopathic effect (observed in infected cells) are used for experiments employing commonly used cell lines. HSV-1 strain KOS was originally isolated from a human labial lesion and is frequently used to investigate HSV-1 gene function and pathogenesis. HSV-1 strain KOS has been identified to show striking differences from some HSV-1 and HSV-2 strains in capability of suppressing the host cell protein synthesis known as the host shutoff function (vhs - virion host shutoff). Although this moderately pathogenic strain of HSV-1 (non-pathogenic for DBA/2 mice) has pronounced shutoff activity determined by its genetic makeup it is less virulent than other HSV-1 strains, such as McKrae, 17 and ANGpath (Luker et al., 2006; Matis and Kúdelová, 2001). Thus, study of this HSV-1 strain herein may contribute to present knowledge about the role of vhs protein in virus evasion from host defense through suppression of cytokine production and reduction of activities of IFNs. Highly pathogenic HSV-1 strain ANGpath originated in the course of serial passages of HSV-1 ANG standard in mouse brain and, in contrast to its parent, kills adult DBA/2 mice even at very low doses of virus upon intra peritoneal infection (Kaerner et al., 1983). It is characterized by syncytial (syn) phenotype of cytopathic effect like most of the clinical isolates of HSV-1. Polycaryocyte formation in infected cells creates for virus partial, but not entirely sufficient advantage facilitating better cell-to-cell spread. Differences between two strains offer the potential for in vivo and/or in vitro studies and identification/evaluation of viral and host factors involved in viral pathogenesis.

Vero cells used in this study contain a genetic deletion in the IFN- $\beta$ locus (Emeny and Morgan, 1979; Mosca and Pitha, 1986; Wathelet et al., 1992) and are the most probably deficient in ability to produce any effective antiviral cytokines, not only the type I IFNs, but also the IFN- $\lambda$ family members. Moreover, they are unable to induce an IFN-dependent expression of IFN-stimulated genes (ISGs) and mount an antiviral response against viruses in an IFN-independent manner (Chew et al., 2009). Being also extremely permissive to viral infection, Vero cells are widely used to perform IFN bioassays and to study virus - host interactions.

Another cell line - Vero E6 cells, was shown to be able to synthesize IFN- $\lambda$ in response to viral infection, but this cell line has sustained a genetic deletion that ablated the type I IFN locus. Moreover, production of a transcription factor, interferon regulatory factor 3 (IRF3), necessary for generating responses to virus infection, encoded by Vero E6 cells is relatively inefficient, resulting in a muted initial response to virus infection. However, Vero E6 cells secrete IFN- $\lambda$ in response to viral infection and this reaction can in turn elicit downstream biological processes, such as induction of interferon stimulated genes (ISGs) expression (Prescott et al., 2010).

Recent studies suggest that type III IFNs act in a more celltype specific manner to mediate their biological functions. In 
this study, we examined the IFN- $\lambda 1$-induced antiviral activity against HSV-1 in vitro by comparing (a) a highly pathogenic ANGpath strain with a moderately pathogenic KOS strain, (b) Vero cells, known as deficient in production of IFNs of type I with Vero E6 cells responding to viral infection with abundant IFN- $\lambda$ production and (c) a high (3 PFU/cell) with a low (0.01 PFU/cell) MOI to study one replication cycle of HSV-1 and more replication cycles of HSV-1 respectively. The obtained results indicated a stronger antiviral activity against ANGpath strain compared to KOS strain. To our best knowledge this is the first report on interface between IFN- $\lambda$ antiviral activity and pathogenicity of virus.

\section{Materials and Methods}

Cells and viruses. The Vero cell line derived from African Green monkey kidney epithelia (ATCC CCL-81) and Vero E6 cell line (ATCC CRL-1586) (kindly provided by Dr. B. Klempa, Institute of Virology, Slovak Academy of Sciences, Slovak Republic) was grown in Dulbecco's Modified Eagle's Medium (Sigma-Aldrich) supplemented with $5 \%(\mathrm{v} / \mathrm{v})$ fetal bovine serum, penicillin-streptomycin (Lonza) at $37^{\circ} \mathrm{C}$ in $5 \% \mathrm{CO}_{2}$ atmosphere. Two strains of HSV-1, highly pathogenic ANGpath and mild KOS (kindly provided by Prof. Ch. Knopf, Institute of Virus Research, DKFZ, Germany and by Prof. J. L. Melnick, WHO Collaborating Centre for Virus Reference and Research, Houston, Texas, USA), were propagated and titrated by plaque assay on Vero cells as described earlier (Kaerner et al., 1983).

Interferon lambda treatment. Vero cells monolayer was incubated with different concentrations of recombinant human IFN- $\lambda 1$ (R\&D Systems) - 10, 15, 20, 25, 30, 35, 40, 70, 100, and $130 \mathrm{ng} / \mathrm{ml}$ (data not shown) for $24 \mathrm{hr}$. Subsequently, the cells were infected with ANGpath or KOS at multiplicity of infection (MOI) of 0.01 or $3 \mathrm{PFU} / \mathrm{cell}$. Twenty hours post infection the cells were plaque assayed to determine virus load and compared to that determined in concurrently infected cells without IFN- $\lambda 1$ treatment.

Single-cycle and multi-cycle growth curves of ANGpath and KOS. To determine growth curves both for ANGpath and KOS in Vero cells, we used the concentration $35 \mathrm{ng} / \mathrm{ml}$ of IFN- $\lambda 1$ to treat the cells. Then, the cells were infected with ANGpath or KOS either at MOI of 3 or 0.01 (PFU/cell) and harvested, lysed by freeze-thaw cycle, and plaque assayed at different intervals - 0, 3, 5, 7.5, 10, 12 , $14,16,18,20 \mathrm{hr}$ p.i. and at the same time points but prolonged to $24,28,32,36,40,44,48,52,60,72 \mathrm{hr}$ p.i. to determine single-cycle and multi-cycle growth curves, respectively. As negative controls, growth curves of ANGpath and KOS in Vero cells untreated with IFN- $\lambda 1$ were determined. The same schedule was used to determine growth curves of ANGpath and KOS in Vero E6 cells producing endogenous IFN- $\lambda 1$ (Prescott et al., 2010). All samples were tested in duplicate. From parallel wells of samples used to determine single-cycle growth curves of ANGpath and KOS total DNA was extracted using the QiaAmp DNA mini kit (Qiagen) and copy number of virus was determined by real-time PCR.
Real-time PCR. Copy number of ANGpath and KOS in infected cells treated or untreated with IFN- $\lambda 1$, were performed by realtime PCR using Maxima SYBR Green/ROX qPCR master mix (Fermentas) following manufacturer's instructions. The amplification of a 377 bp long fragment of gp061 gene coding for DNA binding protein of HSV-1 (NC001806.1) was performed with a pair of primers (forward: 5' $5^{\prime}$ TGT GGT CGT CGA CGA TTG CAG CAT-3'; reverse: 5' -TGG GAG TGA CCC GCG TGG TCG A-3') and cycling conditions $\left(95^{\circ} \mathrm{C} / 10 \mathrm{~min}, 40 \mathrm{x}\left(95^{\circ} \mathrm{C} / 15 \mathrm{sec}, 55.6^{\circ} \mathrm{C} / 30\right.\right.$ $\mathrm{sec}, 72^{\circ} \mathrm{C} / 30 \mathrm{sec}$ ) in a thermal cycler (StepOne, Applied Biosystems, USA). The real time PCR mixture included $0.6 \mu \mathrm{mol} / \mathrm{l}$ of the forward and reverse primer and $1 \mathrm{ng}$ of sampled total DNA in the volume of $25 \mu \mathrm{l}$. All samples were tested in triplicate. Copy number of virus in samples was determined by Applied Biosystems StepOne software v2.2.2, with the detection limit of one copy identified from standard curve created for recombinant plasmid prepared by cloning of a $377 \mathrm{bp}$ long fragment of gp061 gene (amplified as mentioned above) to pGEM-T Easy vector (Promega) according to instruction of manufacturer.

Statistical analysis. All data were expressed as mean \pm SD from three individual experiments. Statistical significance was determined by Student's $t$ test. $\mathrm{P}<0.05$ was considered significant.

\section{Results}

\section{Optimization of IFN- $\lambda$ pretreatment of Vero cells}

We first identified the best choice of IFN- $\lambda 1$ concentration to be used to induce an antiviral response in Vero cells infected with highly pathogenic ANGpath or moderately pathogenic KOS. The IFN- $\lambda 1$ induced antiviral activity was stronger when low doses (MOI of 0.01 ) of each virus strain were used. We found that the decline of ANGpath titer was lower (by about $0.2 \log _{10} \mathrm{PFU} / \mathrm{ml}$ ) than that of KOS $(0.5$ $\log _{10} \mathrm{PFU} / \mathrm{ml}$ ) at interval $20 \mathrm{hr}$ p.i. In Vero cells, $35 \mathrm{ng} / \mathrm{ml}$ IFN- $\lambda 1$ exerted the strongest antiviral activity against both ANGpath and KOS, thus we used this concentration in following experiments.

Effect of IFN- $\lambda$ treatment on Vero cells infected with ANGpath or KOS (single-cycle growth curves)

When we examined an antiviral response activated by IFN- $\lambda 1(35 \mathrm{ng} / \mathrm{ml})$ in pretreated Vero cells infected with high virus dose (MOI of 3 ), we found that single-cycle growth curves of ANGpath and KOS were similar up to $14 \mathrm{hr}$ p.i. Later on, we identified the difference between tested HSV-1 strains. As can be seen in Fig. 1a, after previous increase at earlier time points the titer of ANGpath decreased from 14 to $18 \mathrm{hr}$ p.i. while the titer of KOS was increased in all time points (Fig. 2a). Real-time PCR analyses confirmed the 
difference found between ANGpath and KOS when copy number of ANGpath genome in treated $v s$ untreated Vero cells with IFN- $\lambda 1$ decreased at $18\left(1.45 \times 10^{6} v s .2 .54 \times 10^{6}\right)$ and 20 hr p.i. $\left(1.09 \times 10^{6}\right.$ vs. $\left.3.41 \times 10^{6}\right)$ (Fig. 1 b) but that of KOS genome decreased only in last interval as late as at $20 \mathrm{hr}$ p.i. $\left(2.02 \times 10^{6}\right.$ vs. $\left.6.79 \times 10^{6}\right)$ (Fig. 2b).

Effect of IFN- $\lambda$ on Vero E6 cells infected with ANGpath or KOS (single-cycle growth curves)

When we examined the effect of endogenous IFN- $\lambda 1$ induced in Vero E6 cells after infection with ANGpath or KOS (MOI of 3 ) we found some stimulatory effect on replication of both viruses at all early time points up to $18 \mathrm{hr}$ p.i. However, in comparison to Vero cells viral copy number of
ANGpath in VeroE6 cells was slightly reduced at $18 \mathrm{hr}$ p.i. $\left(2.38 \times 10^{6}\right.$ vs. $2.54 \times 10^{6}$ copies) but more visibly two hours later $\left(2.68 \times 10^{6} v s .3 .41 \times 10^{6}\right)$ (Fig. 1 b).

When comparing Vero E6 and Vero cells infected with KOS we observed almost identical single-cycle growth curves from 16 to 20 hr p.i. (Fig. 2a), but viral copy number decreased at

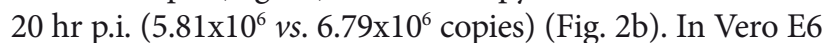
cells, finding of about two times smaller viral copy number of ANGpath than that of $\operatorname{KOS}\left(2.68 \times 10^{6} v s .5 .81 \times 10^{6}\right.$ copies $)$ at late time point confirmed stronger antiviral response (induced by secreted endogenous IFN- $\lambda$ ) to infection with ANGpath.

We concluded that both exogenous IFN- $\lambda 1$ and endogenous IFN- $\lambda$ exert stronger and about $2 \mathrm{hr}$ earlier antiviral response against ANGpath than against KOS in both cell types, Vero and Vero E6, infected with high dose of virus. (a)

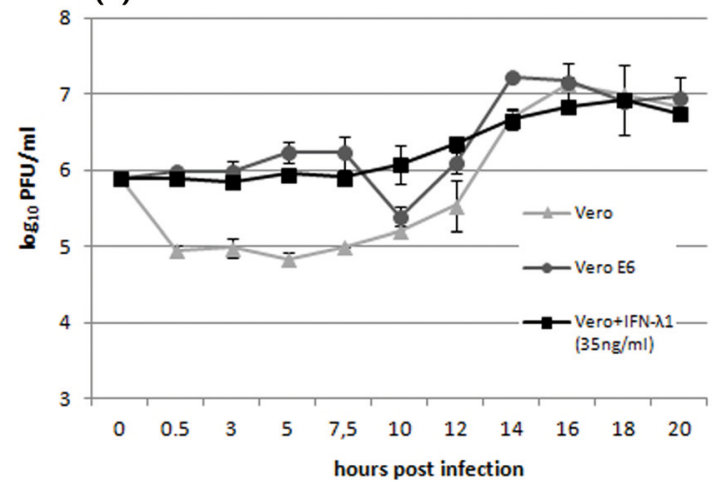

(b)

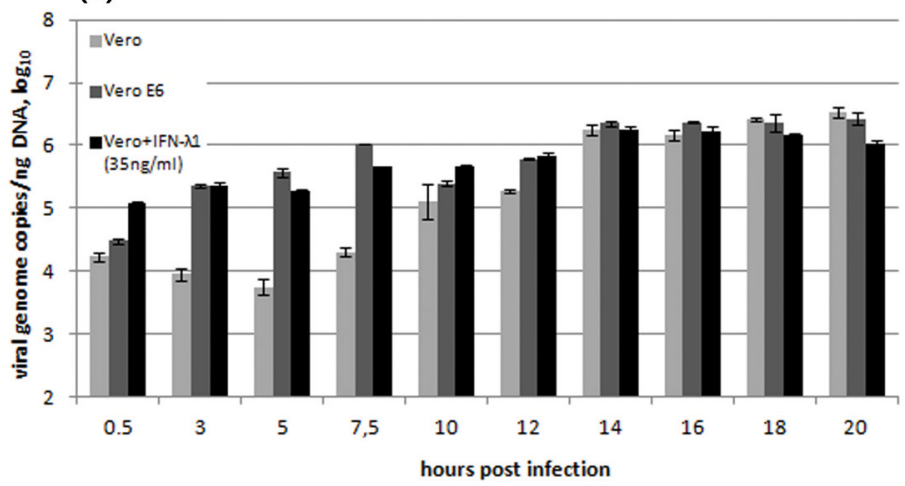

Fig. 1

Single-cycle growth curves of ANGpath strain of HSV-1 in Vero cells pretreated with IFN- $\lambda 1$ and Vero E6 cells The cells were pretreated with $35 \mathrm{ng} / \mathrm{ml}$ of IFN- $\lambda 1$. Vero and Vero E6 cells were infected with the virus at MOI of 3 and assayed for virus load (a) and virus copy number (b).

(a)

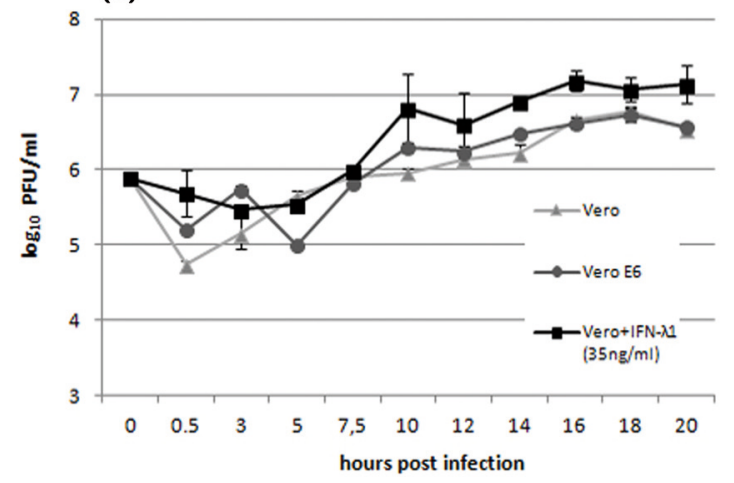

(b)

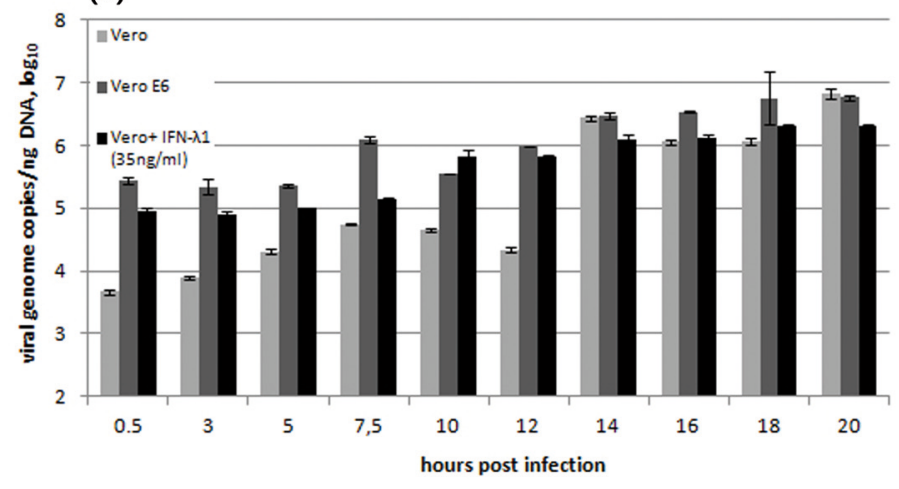

Fig. 2

Single-cycle growth curves of KOS strain of HSV-1 in Vero cells pretreated with IFN- $\lambda 1$ and Vero E6 cells Vero cells were pretreated with $35 \mathrm{ng} / \mathrm{ml}$ of IFN- $\lambda 1$. Vero and Vero E6 cells were infected with the virus at MOI of 3 and assayed for virus load (a) and virus copy number (b). 
(a)

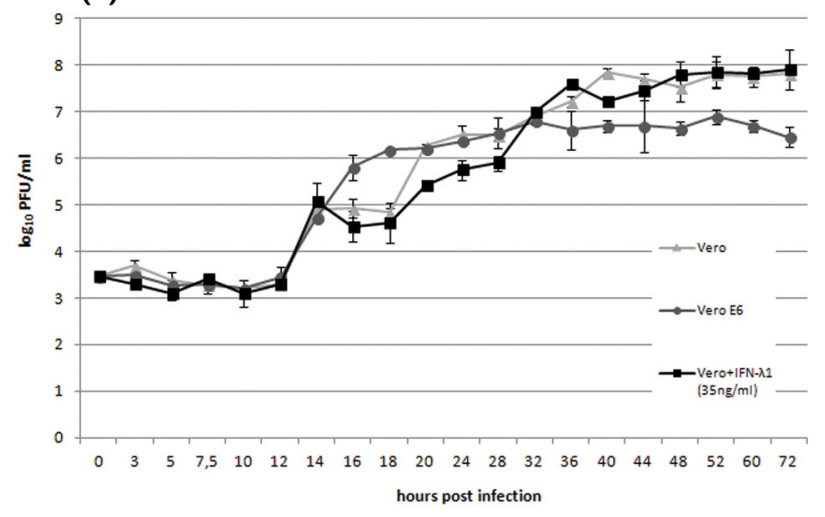

(b)

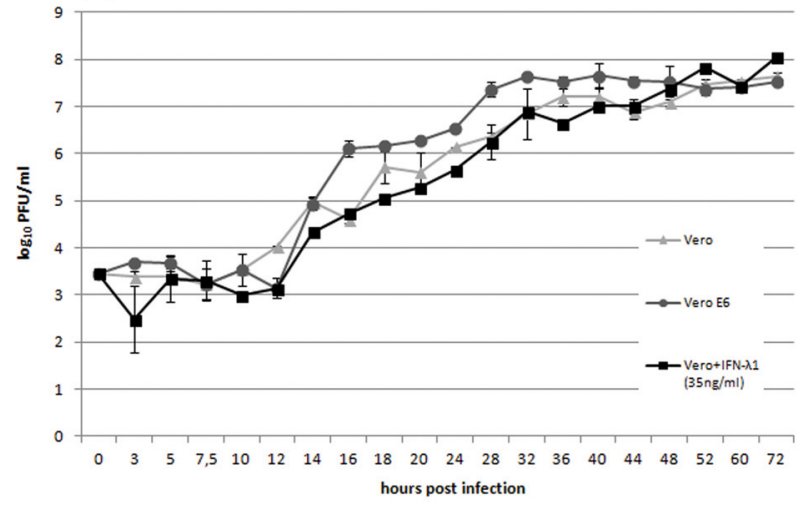

Fig. 3

Multi-cycle growth curves of ANGpath (a) and KOS (b) strains of HSV-1 in Vero cells pretreated with IFN- $\lambda 1$ and Vero E6 cells Vero cells were pretreated with $35 \mathrm{ng} / \mathrm{ml}$ of IFN- $\lambda 1$. Vero and Vero E6 cells were infected with viruses at MOI of 0.01 and assayed for virus load.

Effect of IFN- $\lambda$ treatment on Vero cells infected with ANGpath or KOS (multi-cycle growth curves)

To determine the IFN- $\lambda 1$ induced antiviral activity against herpesvirus progeny, we infected Vero and Vero E6 cells with low dose of virus (MOI of 0.01) comparing ANGpath and KOS. As seen in multi-cycle growth curve of ANGpath in pretreated Vero cells, virus titer declined from 14 to 32 hr p.i. and afterward, except for $40 \mathrm{hr}$ p.i., the growth curve was almost identical with that in cells untreated with IFN- $\lambda 1$. The largest decline $\left(0.8 \log _{10} \mathrm{PFU} / \mathrm{ml}\right)$ of ANGpath titer was observed $20 \mathrm{hr}$ p.i. (Fig. 3a) illustrating antiviral activity of IFN- $\lambda 1$ against virus. In Vero cells infected with KOS only slight IFN- $\lambda 1$ induced inhibition of virus replication was observed at all time points up to $44 \mathrm{hr}$ p.i. followed by slight stimulatory effect noticeable up to $72 \mathrm{hr}$ p.i. (Fig. 3b).

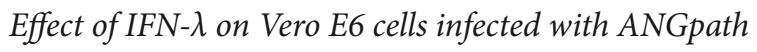
or KOS (multi-cycle growth curves)

In experiments on antiviral activity of endogenous IFN$\lambda 1$ expressed in Vero E6 cells infected with low virus dose (MOI of 0.01) of ANGpath, we found distinct antiviral activity against ANGpath and KOS in all time points after $32 \mathrm{hr}$ p.i. After some stimulatory effect on ANGpath replication induced by IFN- $\lambda 1$ observed at 16 and $18 \mathrm{hr}$ p.i. (Fig. 3a), the decline of virus titer was observed reaching the largest value $\left(1.36 \log _{10} \mathrm{PFU} / \mathrm{ml}\right.$ ) at late time point (72 hr p.i.) (Fig. 3a). These results correlate with previous findings observed in single-cycle growth curve analysis. In contrast to ANGpath, none antiviral but some stimulatory effect induced by IFN- $\lambda 1$ was found in Vero E6 cells infected with KOS up to $52 \mathrm{hr}$ p.i. (Fig. 3b). Later on, both growth curves of Vero E6 and Vero cells were found almost identical.

\section{Discussion}

IFN- $\lambda$ family members display the antiviral activity against several RNA viruses however; there is limited number of reports concerning DNA viruses. To identify an antiviral response induced by exogenous IFN- $\lambda 1$ in Vero cells and endogenous IFN- $\lambda$ in Vero E6 cells, we examined two HSV-1 strain variants in pathogenicity and cytopathic effect - highly pathogenic ANGpath characterized by syncytial phenotype and nonsyncytial moderately pathogenic KOS.

Since the Vero cells are deficient in any effective cytokine production (Emeny and Morgan, 1979; Mosca and Pitha, 1986; Wathelet et al., 1992), including the interferons, before the infection with ANGpath or KOS (at MOI of 0.01 or 3) we pretreated the Vero cells with different concentrations of IFN- $\lambda 1$. We identified the optimal concentration of IFN- $\lambda 1$ (35 ng/ml), when the strongest antiviral activity against ANGpath and KOS was observed (data not shown). The antiviral activity of IFN- $\lambda 1$ was stronger when low dose of virus was used (at MOI of 0.01). These results meet earlier finding that IFN- $\lambda 1$ displayed the modest inhibitory effect on HSV-2, when HepG2 cells were infected with low dose of virus (at MOI of 0.015 ) using as much as $10^{3} \mathrm{ng} / \mathrm{ml}$ IFN- $\lambda 1$ (Ank et al., 2006). According to our results, lower concentration of IFN- $\lambda 1$ was needed to inhibit HSV-1 replication at similar MOI than in the case of HSV-2.

Analysis of single-cycle growth curves of ANGpath and KOS replicated in pretreated Vero cells revealed the difference between these two strains. In cells infected with ANGpath, titer of virus decreased from 14 to $18 \mathrm{hr}$ p.i., as confirmed by the values of virus copy number identified by real-time PCR. On the other hand, no titer decrease of KOS was observed at all time points while genome copy number 
decreased only at the last point at $20 \mathrm{hr}$ p.i. It is known that IFNs can induce the expression of a large number of genes termed ISGs leading to induction of the antiviral state. Ank et al. (2006) proved that IFN- $\lambda 1$ and IFN- $\lambda$ induce protein kinase $\mathrm{R}$ (PKR), ISG56, and 2 ' -5 ' -oligoadenylate synthase to the same extent in different treated cell lines. All these ISGs could be induced after 2 hours long stimulation and their levels remained high also after 24 hours. However, the HSV-1 tegument contains viral proteins interacting with and inhibiting cellular signalling pathways. At high MOI, there is a high concentration of these viral proteins in the cell. Although IFN- $\lambda 1$ can induce the expression of ISGs in vitro, such an infection is unnatural for the virus and its host and the proteins with antiviral activity appear not to be sufficient to protect cells against high dose of highly pathogenic strain ANGpath and moderately pathogenic strain KOS.

We observed similar difference between ANGpath and KOS during multi-cycle growth curves (at MOI of 0.01) of both viruses replicated in pretreated Vero cells. The titer of strain ANGpath declined from 14 to $32 \mathrm{hr}$ p.i. (the largest decline was $0.8 \log _{10}$ PFU/ml) and afterward, except for 40 hr p.i., was comparable with that found in untreated cells. On the other hand, only slight inhibition of KOS replication was observed at all time points up to $44 \mathrm{hr}$ p.i. followed even by slight stimulatory effect. We concluded that inhibition effect of exogenous IFN- $\lambda 1$ on replication of moderately pathogenic strain KOS is weaker than that of highly pathogenic strain ANGpath.

In following study on the effect of endogenous IFN- $\lambda$ we compared antiviral response against ANGpath and KOS in Vero E6 cells, in which the secretion of IFN- $\lambda$ is induced in response to viral infection (Prescott et al., 2010). Analysis of single cycle growth curves of Vero E6 cells infected with high dose of ANGpath or KOS revealed for both viruses almost identical titer up to $18 \mathrm{hrs}$ p.i. and similar decrease of copy number of their genome after $20 \mathrm{hr}$ p.i. However, we observed about two times smaller genome copy number of ANGpath than that of $\operatorname{KOS}\left(2.68 \times 10^{6} v s .5 .81 \times 10^{6}\right.$ copies $)$ at late time point. The results confirmed our previous finding of stronger antiviral response to infection with ANGpath though now it was induced by endogenous IFN- $\lambda 1$ secreted by cells.

We have also found different antiviral activity against ANGpath and KOS in multi-cycle replication study of these viruses in Vero E6 cells infected with low virus dose. While titer of ANGpath decreased, the most visibly at late time points, none antiviral but some stimulatory effect induced by IFN- $\lambda 1$ was found in Vero E6 cells infected with KOS up to $48 \mathrm{hr}$ p.i. These results correlate with previous findings obtained from single-cycle growth curve analyses. The delay of antiviral effect against ANGpath observed in Vero E6 in comparison to pretreated Vero cells could be explained by the necessity of IFN- $\lambda$ expression as a respond to virus infection in Vero E6 cells and subsequent stimulation of other cytokines and ISGs expression in later time points of infection. When the virus infects Vero cells pretreated with IFN- $\lambda 1$, the expression of ISGs has already been activated.

Our results resemble the results of Pasieka et al. (2008), who found that the replication of wild-type strain KOS was almost unaffected by IFN- $\alpha$ at concentration of $100 \mathrm{U} / \mathrm{ml}$ in mice embryonic primary cells infected at MOI of 0.01 . This phenomenon was observed also in human cells and might probably indicate an important role of vhs protein in mechanisms involved in antiviral response of cells infected with HSV-1. Vhs protein (encoded by UL41 gene), a component of tegument of HSV-1 and HSV-2, possesses both endo- and exonuclease activity and mediates the rapid shutoff of protein synthesis via degradation of cellular mRNA. The function of vhs protein can be inhibited by interaction with the alpha trans-inducing factor ( $\alpha$-TIF) engaged in the earliest stages of infection. Schmelter et al. (1996) demonstrated that the 21 amino acid long domain encompassing vhs residues 310 to 330 is sufficient for interaction with $\alpha$-TIF. Previous studies revealed the presence of two mutations in the sequence encoding vhs protein of strain KOS (Matis and Kúdelová, 2001). The mutation causing replacement of threonine to methionine at position 317 of vhs protein of strain KOS was assumed to play a role in the increased shutoff activity of this strain in comparison to several HSV-1 strains including ANGpath (Vojvodová et al., 1997). Thus, our results may suggest that pronounced shutoff activity of KOS could suppress the IFN- $\lambda 1$ induced antiviral response to virus infection. Earlier studies confirmed that the shutoff function of vhs protein may result also in inhibition of TLR2, TLR3, Retinoic acid-inducible gene-I (RIG-I)/melanoma differentiation-associated protein 5 , but also IRF3 and reduction of activity of Janus kinase 1 (Jak1) and Signal transducer and activator of transcription 2 (STAT2) in the Jak/STAT signalling pathway activated by IFNs (Murphy et al., 2003; Yao and Rosenthal, 2011). It is also known that vhs protein may minimize the accumulation of viral RNA below the levels detected by RNA sensing molecules such as RIG-I and below those that trigger antiviral pathways such as PKR and RNase L (Pasieka et al., 2008). Likewise, it may be assumed that the syn phenotype of strain ANGpath could strengthen antiviral activity induced by IFN- $\lambda 1$ observed in this study. Syncytium - giant fused cells occurring after the infection with syn HSV-1 strains may offer a suitable environment for synergistic action of ISGs proteins resulting in stronger antiviral response against syn HSV-1 strains than against non-syn ones. These ideas need further investigation.

In conclusion, we found that IFN- $\lambda 1$ is able to defend against HSV-1 infection in dose dependent manner. During single-cycle replication of HSV-1 in Vero cells, exogenous IFN- $\lambda 1$ is able to induce antiviral response only at late time point (20 hr p.i.). During multi-cycle replication of HSV-1, 
the antiviral response activated in pretreated Vero cells and in Vero E6 cells expressing endogenous IFN- $\lambda$ is stronger against highly pathogenic strain ANGpath than against moderately pathogenic strain KOS. To our best knowledge this is the first report concerning Vero and Vero E6 cells antiviral activity induced by IFN- $\lambda$ and pathogenicity/ phenotype of two strains of HSV-1, ANGpath and KOS. Following studies are in the progress to reveal new aspects regarding the characteristics of antiviral activity inducible by novel cytokine IFN- $\lambda 1$ against HSV- 1 as well as the role of IFN- $\lambda 1$ in virus-host interactions.

Acknowledgement. This publication is the result of the project implementation: Comenius University in Bratislava Science Park supported by the Research and Development Operational Programme funded by the ERDF Grant No.: ITMS 26240220086. This work was supported by the grants Nos. 1/0265/11 and 2/0185/12 from Slovak Grant Agency of Ministry of Education of Slovak Academy of Sciences, contract No. APVV-0621-12 of Slovak Research and Development Agency and by the grant No. 485/2014 from Comenius University.

\section{References}

Ank N, West H, Bartholdy Ch, Eriksson K, Thomsen AR, Paludan SR (2006): Lambda Interferon (IFN- $\lambda$ ), a type III IFN, is induced by viruses and IFNs and displays potent antiviral activity against select virus infections in vivo. J. Virol. 80, 4501-4509. http://dx.doi.org/10.1128/JVI.80.9.4501$\underline{4509.2006}$

Ank N, Iversen MB, Bartholdy C, Staeheli P, Hartmann R, Jensen UB, Gnaes-Hansen F, Thomsen AR, Chen Z, Haugen H, Klucher K, Paludan SR (2008): An important role for type III interferon (IFN-lambda/IL-28) in TLR-induced antiviral activity. J. Immunol. 180, 2474-2485. http:// dx.doi.org/10.4049/jimmunol.180.4.2474

Ank N, Paludan SR (2009): Type III IFNs: new layers of complexity in innate antiviral immunity. Biofactors 35, 82-87. http:// dx.doi.org/10.1002/biof.19

Chew T, Noyce R, Collins SE, Hancock MH, Mossman KL (2009): Characterization of the interferon regulatory factor 3-mediated antiviral response in a cell line deficient for IFN production. Mol. Immunol. 46, 393-399. http:// dx.doi.org/10.1016/j.molimm.2008.10.010

Coccia EM, Severa M, Giacomini E, Monneron D, Remoli ME, Julkunen I, Cella M, Lande R, Uze G (2004): Viral infection and Toll-like receptor agonists induce a differential expression of type I and lambda interferons in human plasmacytoid and monocyte-derived dendritic cells. Eur. J. Immunol. 34, 796-805. http://dx.doi.org/10.1002/eji.200324610

Donnelly RP, Kotenko SV (2010): Interferon-lambda: a new addition to an old family. Journal of Interferon \& Cytokine Research. 30, 555-564. http://dx.doi.org/10.1089/jir.2010.0078

Emeny JM, Morgan MJ (1979): Regulation of the interferon system: evidence that Vero cells have a genetic defect in interferon production. J. Gen. Virol. 43, 247-252. http://dx.doi. org/10.1099/0022-1317-43-1-247

Guo YJ, Zhao L, Li XF, Mei YW, Zhang SL, Tao JY, Zhou Y, Dong JH (2010): Effect of Corilagin on antiinflammation in HSV-1 encephalitis and HSV-1 infected microglias. Eur. J. Pharmacol. 635, 79-86. http://dx.doi.org/10.1016/j. ejphar.2010.02.049

Kaerner HC, Schröder CH, Ott-Hartmann A, Kümel G, Kirchner $\mathrm{H}$ (1983): Genetic variability of herpes simplex virus: development of a pathogenic variant during passaging of a nonpathogenic herpes simplex virus type 1 virus strain in mouse brain. J. Virol. 46, 83-93.

Kotenko SV, Gallagher G, Baurin VV, Lewis-Antes A, Shen M, Shah NK, Langer JA, Sheikh F, Dickensheets H, Donnelly RP (2003): IFN-lambdas mediate antiviral protection through a distinct class II cytokine receptor complex. Nat. Immunol. 4, 69-77. http://dx.doi.org/10.1038/ni875

Kúdelová M, Rajčáni J (2013): In Singh SK, Ruzek D (Eds): Neuroviral Infections. CRC Press LLC, Boca Raton, Florida, Chapt 7, pp. 169-214. http://dx.doi.org/10.1201/b13907-10

Lafaille FG, Pessach IM, Zhang SY, Ciancanelli MJ, Herman M, Abhyankar A, Ying SW, Keros S, Goldstein PA, Mostoslavsky G, Ordovas-Montanes J, Jouanguy E, Plancoulaine S, Tu E, Elkabetz Y, Al-Muhsen S, Tardieu M, Schlaeger TM, Daley GQ, Abel L, Casanova JL, Studer L, Notarangelo LD (2012): Impaired intrinsic immunity to HSV-1 in human iPSCderived TLR3-deficient CNS cells. Nature 491, 769-773.

Li J, Hu S, Zhou L, Ye L, Wang X, Ho J, Ho W (2011): Interferon lambda inhibits herpes simplex virus type I infection of human astrocytes and neurons. Glia 59, 58-67. http:// dx.doi.org/10.1002/glia.21076

Li J, Ye L, Wang X, Hu SX, Ho WZ (2012): Induction of interferonlambda contributes to Toll-like receptor 3-mediated herpes simplex virus type 1 inhibition in astrocytes. J. Neurosci. Res. 90, 399-406. http://dx.doi.org/10.1002/jnr.22758

Lopušná K, Režuchová I, Betáková T, Skorvanová L, Tomašková J, Lukáčiková L, Kabát P (2013): Interferons lambda, new cytokines with antiviral activity. Acta Virol. 57,171-179. http://dx.doi.org/10.4149/av $2013 \quad 02 \quad 171$

Luker KE, Schultz T, Romine J, Leib DA, Luker GD (2006): Transgenic reporter mouse for bioluminescence imaging of herpes simplex virus 1 infection in living mice. Virology 347, 286-295. http://dx.doi.org/10.1016/j.virol.2005.12.016

Matis J, Kúdelová M (2001): Early shutoff of host protein synthesis in cells infected with herpes simplex viruses. Acta Virol. 45, 269-277.

Mosca JD, Pitha PM (1986): Transcriptional and posttranscriptional regulation of exogenous human beta interferon gene in simian cells defective in interferon synthesis. Mol. Cell Biol. 6, 2279-2283.

Murphy JA, Duerst RJ, Smith TJ, Morrison LA (2003): Herpes simplex virus type 2 virion host shutoff protein regulates alpha/beta interferon but not adaptive immune responses during primary infection in vivo. J. Virol. 77, 9337-9345. http://dx.doi.org/10.1128/JVI.77.17.9337-9345.2003

Onoguchi K, Yoneyama M, Takemura A, Akira S, Taniguchi T, Namiki H, Fujita T (2007): Viral infections activate types 
I and III interferon genes through a common mechanism. J. Biol. Chem. 282, 7576-7581. http://dx.doi.org/10.1074/ jbc.M608618200

Pasieka TJ, Lu B, Crosby SD, Wylie KM, Morrison LA, Alexander DE, Menachery VD, Leib DA (2008): Herpes simplex virus virion host shutoff attenuates establishment of the antiviral state. J. Virol. 82, 5527-5535. http://dx.doi. org/10.1128/JVI.02047-07

Paul S, Ricour C, Sommereyns C, Sorgeloos F, Michiels T (2007): Type I interferon response in the central nervous system. Biochimie 89, 770-778. http://dx.doi.org/10.1016/j. biochi.2007.02.009

Prescott J, Hall P, Acuna-Retamar M, Ye C, Wathelet MG, Ebihara H, Feldmann H, Hjelle B (2010): New World Hantaviruses Activate IFN $\lambda$ Production in Type I IFN-Deficient Vero E6 Cells. PLoS One 5, e11159. http://dx.doi.org/10.1371/ journal.pone.0011159

Prokunina-Olsson L, Muchmore B, Tang W, Pfeiffer RM, Park H, Dickensheets H, Hergott D, Porter-Gill P, Mumy A, Kohaar I, Chen S, Brand N, Tarway M, Liu L, Sheikh F, Astemborski J, Bonkovsky HL, Edlin BR, Howell CD, Morgan TR, Thomas DL, Rehermann B, Donnelly RP, O'Brien TR (2013): A variant upstream of IFNL3 (IL28B) creating a new interferon gene IFNL4 is associated with impaired clearance of hepatitis C virus. Nat. Genet. 45, 164-171. http://dx.doi.org/10.1038/ng.2521

Robek MD, Boyd BS, Chisari FV (2005): Lambda interferon inhibits hepatitis B and C virus replication. J. Virol. 79, 3851-3854. http://dx.doi.org/10.1128/JVI.79.6.3851-3854.2005

Sheppard P, Kindsvogel W, Xu W, Henderson K, Schlutsmeyer S, Whitmore TE, Kuestner R, Garrigues U, Birks C, Roraback J, Ostrander C, Dong D, Shin J, Presnell S, Fox B, Haldeman B, Cooper E, Taft D, Gilbert T, Grant FJ, Tackett M, Krivan W, McKnight G, Clegg C, Foster D, Klucher KM (2003): IL-28, IL-29 and their class II cytokine receptor IL-28R. Nature Immunol. 4, 63-68. http://dx.doi.org/10.1038/ni873

Schmelter J, Knez J, Smiley JR, Capone JP (1996): Identification and characterization of a small modular domain in the herpes simplex virus host shutoff protein sufficient for interaction with VP16. J. Virol. 70, 2124-2131.

Sorgeloos F, Kreit M, Hermant P, Lardinois C, Michiels T (2013): Antiviral type I and type III interferon responses in the central nervous system. Viruses 5, 834-857. http://dx.doi. org $/ 10.3390 / \mathrm{v} 5030834$

Svetlikova D, Kabat P, Ohradanova A, Pastorek J, Betakova $T$ (2010): Influenza A virus replication is inhibited in IFN- $\lambda 2$ and IFN- $\lambda 3$ transfected or stimulated cells. Antiviral Res. 88, 329-333. http://dx.doi.org/10.1016/j. antiviral.2010.10.005

Vojvodová A, Matis J, Kúdelová M, Rajčáni J (1997): Herpes simplex virus type 1 (HSV-1) strain HSZP host shutoff gene: nucleotide sequence and comparison with HSV-1 strains differing in early shutoff of host protein synthesis. Virus Genes 15, 155-159. http://dx.doi.org/10.1023/ $\underline{\text { A:1007915025086 }}$

Wang JP, Bowen GN, Zhou S, Cerny A, Zacharia A, Knipe DM, Finberg RW, Kurt-Jones EA (2012): Role of specific innate immune responses in herpes simplex virus infection of the central nervous system. J. Virol. 86, 2273-2281. http:// dx.doi.org/10.1128/JVI.06010-11

Wathelet MG, Berr PM, Huez GA (1992): Regulation of gene expression by cytokines and virus in human cells lacking the type-I interferon locus. Eur. J. Biochem. 206, 901-910. http://dx.doi.org/10.1111/j.1432-1033.1992.tb16999.x

Yao XD, Rosenthal KL (2011): Herpes simplex virus type 2 virion host shutoff protein suppresses innate dsRNA antiviral pathways in human vaginal epithelial cells. J. Gen. Virol. 92, 1981-1993. http://dx.doi.org/10.1099/ vir.0.030296-0 